\title{
Differentiation of xylem cells in rolC transgenic aspen trees - a study of secondary cell wall development
}

\author{
Claudia Grünwald ${ }^{\mathrm{a} *}$, Katia Ruel ${ }^{\mathrm{b}}$ and Uwe Schmitt ${ }^{\mathrm{c}}$ \\ ${ }^{a}$ Institute for Wood Biology, University of Hamburg, Leuschnerstr. 91, 21031 Hamburg, Germany \\ ${ }^{\mathrm{b}}$ Centre de Recherches sur les Macromolécules Végétales (CERMAV)-CNRS, BP 53, 38041 Grenoble Cedex 9, France \\ ${ }^{\mathrm{c}}$ Institute for Wood Biology and Wood Protection, Federal Research Centre for Forestry and Forest Products, Leuschnerstr. 91, 21031 Hamburg, Germany
}

(Received 16 August 2001; accepted 21 January 2002)

\begin{abstract}
Xylem cell differentiation of 35S-rolC transgenic aspen was analyzed and compared with wild type trees. The transgenic trees, mainly characterized by dwarfism and physiological alterations, did not show distinctive differences in the structure and chemical composition of xylem cell walls as compared with the wild type trees. However, there was a difference in the dynamics of differentiation. In the transgenics the formation of xylem cells was delayed and the differentiation zone reduced to a few rows. PATAg and $\mathrm{KMnO}_{4}$ staining in electron microscopy as well as UV-microspectrophotometry revealed that in the transgenics during secondary wall formation polysaccharides and lignin were simultaneously deposited close to the cambium. Immunocytochemical techniques have visualized the first deposition of condensed lignin in cell corners and of non-condensed lignin in secondary walls near cell corners. Because of altered formation and differentiation of xylem cells, 35S-rolC transgenic aspen may be useful to study factors controlling the differentiation continuum.
\end{abstract}

Populus / rolC / wood formation / lignification / electron microscopy / immunogoldlabelling / UV-microspectrophotometry

Résumé - Différenciation des cellules du xylème chez le peuplier transgénique 35S-rolC - une étude de la formation des parois secondaires. La différenciation des cellules du xylème du peuplier transgénique $35 \mathrm{~S}$-rolC a été analysée et comparée à celle du peuplier non transformé. Les arbres transgéniques nains, qui se caractérisent par des altérations physiologiques et morphologiques ne présentaient pas de différences dans leur architecture ni dans la composition des parois des cellules du xylème par comparaison avec les plantes normales. En revanche, on a pu observer une différence dans la dynamique de la différenciation. Dans les arbres transgéniques, la formation des cellules du xylème est retardée et la zone de différenciation est réduite à quelques rangées de cellules. De ce fait, la formation et la lignification de la paroi secondaire ont pu être observées dans des cellules moins développées que dans le peuplier normal ainsi que cela a été mis en évidence par microspectrophotométrie-UV et par les contrastants PATAg et $\mathrm{KMnO}_{4}$ en microscopie électronique à transmission. Des analyses immunocytochimiques ont révélé la toute première déposition de lignines condensées dans les jonctions intercellulaires et de lignines non condensées dans les parois secondaires adjacentes aux triangles de jonctions. Ces altérations dans la formation et la différenciation des cellules du xylème font du peuplier transgénique 35S-rolC un matériel utile pour l'étude des facteurs contrôlant le continuum de différenciation.

Populus / rolC / formation des cellules du xylème / lignification / microscopie électronique à transmission / immunocytochimie / microspectrophotométrie-UV

\section{INTRODUCTION}

Woody cell walls are composed of cellulose, hemicelluloses, lignin and pectic substances as main components. Each of these has been intensively studied for many years $[4,9,11,17,22,23]$, but nevertheless the knowledge of their biosynthesis, structure and properties as well as their three dimensional assembly in the cell wall is not well understood [32]. Research on this topic is difficult because of the diverse ultrastructure of cell walls between species, plant

* Correspondence and reprints

Tel.: + 494073962 444; fax: + 494042891 2835; e-mail: gruenwald@ holz.uni-hamburg.de 
tissues, cells within tissues and even between different morphological regions of a cell wall. In addition, attempts to separate the components and to elucidate details of their three dimensional assembly, which largely determines wood properties, have mostly been unsuccessful. However, the microstructure of lignified cell walls and the character of the cell wall components from early to late developmental stages of cell wall differentiation can be studied by non-destructive analytical methods such as UV-microspectrophotometry and electron microscopy in combination with immunohistochemical techniques [36].

Transgenic trees with well-pronounced morphological alterations as compared to non-transformed wild type trees have shown utility as model systems to study wood formation in vivo $[8,31]$. Molecular analyses at the gene or protein level $[1,5,25,33,41]$ in combination with ultrastructural analyses of the wood formation process of transgenic and wild type trees possibly enables the identification of factors responsible for modifications expressed in the transgenic trees. The rol genes from Agrobacterium rhizogenes are known to modify the morphology of hardwood trees in general [12, 24, 39, 40]. In the 35S-rolC transgenic aspen trees used in the present study, physiological and morphological traits were distinctly modified [12, 13]. In particular, in the xylem tissue no typical latewood was formed and an unusual high amount of gelatinous fibres was conspicuous; at the cellular level the general morphology of fibres, vessels and parenchyma cells appeared unchanged, although the formation and differentiation of these cells was delayed $[15,16]$.

The objective of the present study was to report more detailed information on the differentiation sequence during cell wall formation in 35S-rolC transgenic aspen trees with suppressed cambium activity. For visualization of the deposition of cell wall components during differentiation of xylem cells, PATAg $(\mathrm{PA}=$ periodic acid, $\mathrm{T}=$ thiocarbohydrazide, $\mathrm{Ag}=$ silver proteinate) and $\mathrm{KMnO}_{4}$ staining, immunogoldlabelling of the most represented lignin sub-units in combination with transmission electron microscopy (TEM) as well as UV-microspectrophotometry of individual fibre wall layers were carried out. Alterations in the differentiation patterns of transgenic and wild type trees are discussed in relation to endogenous mechanisms controlling wood formation.

\section{MATERIALS AND METHODS}

\subsection{Plant material}

One non-transformed hybrid aspen clone of Populus tremula L. $\times$ P. tremuloides Michx. (referred to as wild type) and two independent $35 \mathrm{~S}$-rolC transgenic hybrid aspen clones transformed with the rolC gene under the control of the constitutive cauliflower-35S-promoter $[12,14]$ were available. In the following all $35 \mathrm{~S}-$ rolC transgenic trees are referred to as transgenics, because the same differentiation of xylem cells was observed for both transgenic clones. The trees were three years old and greenhouse cultivated in
$5 \mathrm{~L}$ containers, with changing natural daylight and temperature, minimum temperatures during winter around $8-10{ }^{\circ} \mathrm{C}$ and maximum temperatures during summer around $25-30^{\circ} \mathrm{C}$. The trees were watered daily and fertilized 2-3 times a year.

\subsection{Light-microscopy}

For light-microscopy of the differentiating xylem stem portions of 14 wild type and 33 transgenic trees were prepared as follows: $3-5$ small cubes $\left(5 \times 5 \times 5 \mathrm{~mm}^{3}\right)$ including bark, cambium and developing xylem were dissected from each tree at $50 \mathrm{~cm}$ above ground, immediately fixed in a phosphate-buffered solution of $37 \%$ formaldehyde for $24 \mathrm{~h}$, dehydrated in propanol and embedded in glycol methacrylate (Technovit 7100). $8 \mu \mathrm{m}$ thick transversal sections were cut with a rotary microtome, stained with a standard Giemsa solution and mounted on glass slides using Euparal.

\subsection{Immunocytochemistry and transmission electron-microscopy (TEM)}

Samples with $1 \times 1 \times 4 \mathrm{~mm}^{3}$ in size containing bark, cambium tissue and developing xylem were fixed in a freshly prepared mixture of 5\% glutaraldehyde and $8 \%$ paraformaldehyde for $24 \mathrm{~h}$, washed in $0.1 \mathrm{M}$ cacodylate buffer, dehydrated through a graded series of acetone and embedded in Spurr's epoxy resin. Ultrathin transverse sections were cut, placed on copper grids, stained with $\mathrm{KMnO}_{4}$ according to Donaldson [10] and examined with a Philips CM12 TEM at an accelerating voltage of $60 \mathrm{kV}$. PATAg staining (Thiéry [37], modified by Ruel et al. [26, 27]) and immunogoldlabelling were carried out with samples from one wild type and two transgenic trees. They were fixed in a freshly prepared mixture of $0.2 \%$ glutaraldehyde and $4 \%$ paraformaldehyde in $0.05 \mathrm{M}$ phosphate buffer ( $\mathrm{pH} 7-7.2)$ for $24 \mathrm{~h}$, rinsed in phosphate buffer, dehydrated through a graded series of ethanol, infiltrated and embedded in LR White resin (hard mixture, TAAB). Immunogoldlabelling was done on 50-60 nm thick transversal sections floating on plastic rings according to Ruel et al. [29]. Polyclonal lignin antibodies raised in rabbit against condensed guaiacyl-syringyl (GS), non-condensed GS and condensed guaiacyl (G) synthetic dehydrogenative polymers $[18,28]$ were used for the first incubation. The sections were floated on each antiserum diluted 1/50-1/80. Protein A-gold, pA 5 (Amersham) was used as a secondary marker. After silver enhancement (Amersham), the thin-sections were transferred onto copper grids, poststained with $2.5 \%$ aqueous uranyl acetate and examined with the Philips CM12 TEM at an accelerating voltage of $80 \mathrm{kV}$. Control samples were treated as described above except that the primary antibody was omitted from incubation solution.

\subsection{Determination of lignin in specific cell wall layers by UV-microspectrophotometry}

UV-spectroscopic measurements were carried out on three wild type and transgenic trees, respectively. The samples with $1 \times 1 \times 4 \mathrm{~mm}^{3}$ in size containing bark, cambium and differentiating xylem were embedded in Spurr's epoxy resin as described above. Transverse sections of $1 \mu \mathrm{m}$ thickness were cut and mounted on quartz slides, immersed in glycerine and covered with quartz coverslips. UV-spectra were taken at wavelengths from 240 to $400 \mathrm{~nm}$ in $2 \mathrm{~nm}$ steps using a Zeiss UMSP 80 microspectrophotometer [19]. Point measurements of the lignin content were repeated 50 times at each step for middle lamella regions and developing outer secondary 
walls (close to the middle lamella) with increasing distance from the cambium. Measurements of the secondary walls were started ten to twelve cells away from the cambium.

\section{RESULTS}

The wild type trees exhibited a broad differentiation zone clearly separated into sub-zones where cell division, cell enlargement and secondary wall formation were taking place (figure 1a). PATAg staining revealed the absence of secondary walls close to the cambium (figure $1 b$ ). The deposition of secondary wall polysaccharides started about seven to nine cell rows from the cambium and slowly progressed with increasing distance. In contrast, the transgenic tree differentiation zones were reduced to a few cell rows with no sub-zonation evident (figure 1c). Secondary walls already occurred two to three cells from the cambium. Some cells with a rather thick secondary wall and sometimes even with a gelatinous layer formed an atypical thin radial wall centrally dividing the cell into two compartments (figure 1d).

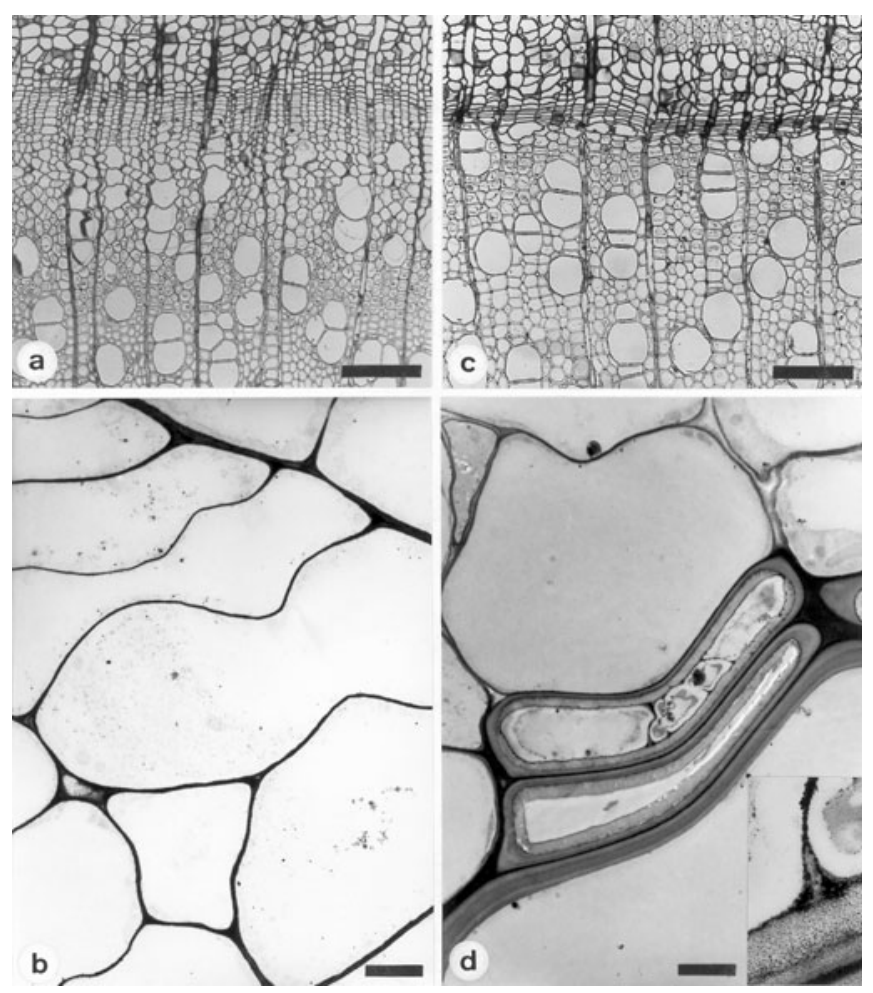

Figure 1. (a, b) Wild type trees. (a) Broad differentiation zone, Giemsa staining, light micrograph. Bar $=100 \mu \mathrm{m}$. (b) No secondary wall formation close to the cambium, PATAg staining, electron micrograph. Bar $=2.5 \mu \mathrm{m}$.

(c, d) 35S-rolC transgenic trees. (c) Differentiation zone reduced to a few rows, Giemsa staining, light micrograph. Bar $=100 \mu \mathrm{m}$. (d) Formation of secondary walls and gelatinous layers (pale stained inner wall layers) close to the cambium, even in dividing cells, PATAg staining, electron micrograph. $\mathrm{Bar}=2.5 \mu \mathrm{m}$.
Staining with $\mathrm{KMnO} 4$ revealed that in the wild type trees lignification proceeded with a distinct delay to polysaccharide deposition. Cell corners and middle lamellae were increasingly stained with increasing distance to the cambium. S1 lignification started in outer portions during S2 polysaccharide deposition. It later extended towards inner portions of the S1 and subsequently to the S2 layer (figures $2 a-c$ ). In contrast, in the transgenics even cells close to the cambium showed a distinct and homogeneous lignification

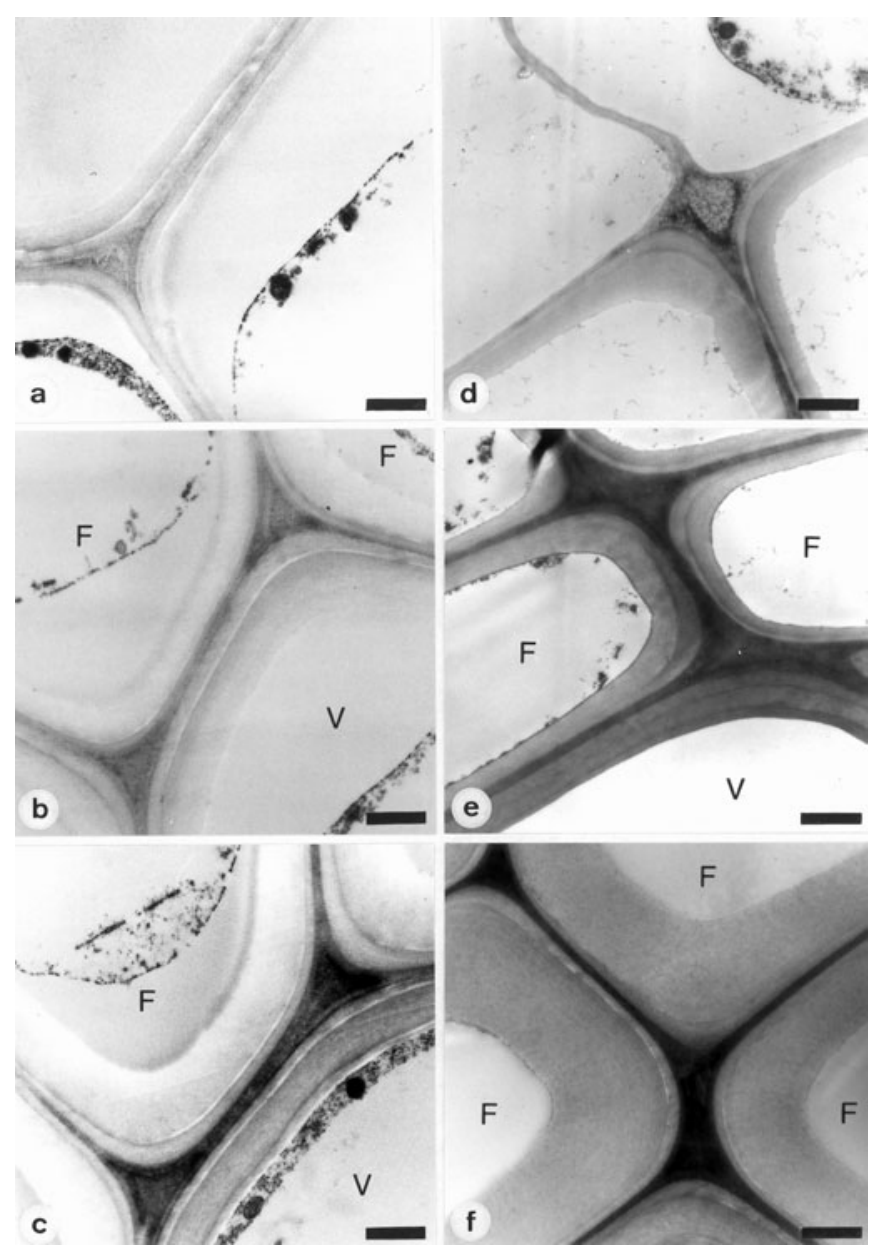

Figure 2. (a-c) Wild type trees, electron micrographs, $\mathrm{KMnO}_{4}$ staining. $\mathrm{F}=$ Fibre, $\mathrm{V}=$ Vessel. Bars $=1 \mu \mathrm{m}$. (a) Cell corners and middle lamellae slightly stained, 9-10 cell rows from the cambium. (b) Cell corners and middle lamellae increasingly stained, vessel secondary walls slightly stained, 13-14 cell rows from the cambium. (c) Cell corners, middle lamellae and vessel walls distinctly stained, outer secondary walls of fibres slightly stained, inner secondary walls unstained, 17-18 cell rows from the cambium.

(d-f) 35S-rolC transgenic trees, electron micrographs, $\mathrm{KMnO}_{4}$ staining. $\mathrm{F}=$ Fibre, $\mathrm{V}=$ Vessel. Bars $=1 \mu \mathrm{m}$. (d), 1-2 cell rows from the cambium. (e) Intense staining of cell corners, middle lamellae and developing secondary walls, 3-4 cell rows from the cambium. (f) Mature fibre walls with intense staining, 15-16 cell rows from the cambium. 
of their S1 and also of the S2 layer already undergoing formation in this region (figures $2 d, e$ ). With increasing distance to the cambium the S2 layers became thicker, but no staining gradient within this layer could be seen (figures $2 d-f$ ).

Figure 3 shows examples of UV-spectra measured in middle lamella regions $(M)$ and outer secondary walls $(S)$ of differentiating fibres in a wild type $(a)$ and a transgenic $(b)$ tree. Absorption at about $272 \mathrm{~nm}$ indicating lignification of middle lamella regions and outer secondary walls generally increased with increasing distance to the cambium (1-4). The transgenic tree showed a higher lignification already within the first 10 cell rows (figure $3 \mathrm{blM}$ ) reaching maximum values in both portions $(\mathrm{M}=0.25, \mathrm{~S}=0.18)$ already 20 cell rows distant to the cambium (figure $3 b 2 M, b 2 S$ ). The wild type, however, had much lower absorption levels $(\mathrm{M}=0.1$, $\mathrm{S}=0.02$ ) in the first 20 cell rows from the cambium (figure 3 $a 2 M, a 2 S)$. Up to cell row 40, absorption values slowly increased up to 0.2 for the middle lamella regions (figure 3 $a 4 M$ ) and 0.1 for the outer secondary walls (figure $3 a 4 S$ ).

In figure 4, the absorption values at $272 \mathrm{~nm}$ were plotted against the distance to the cambium. It is shown for the transgenic tree that absorption of middle lamella regions (a) Control
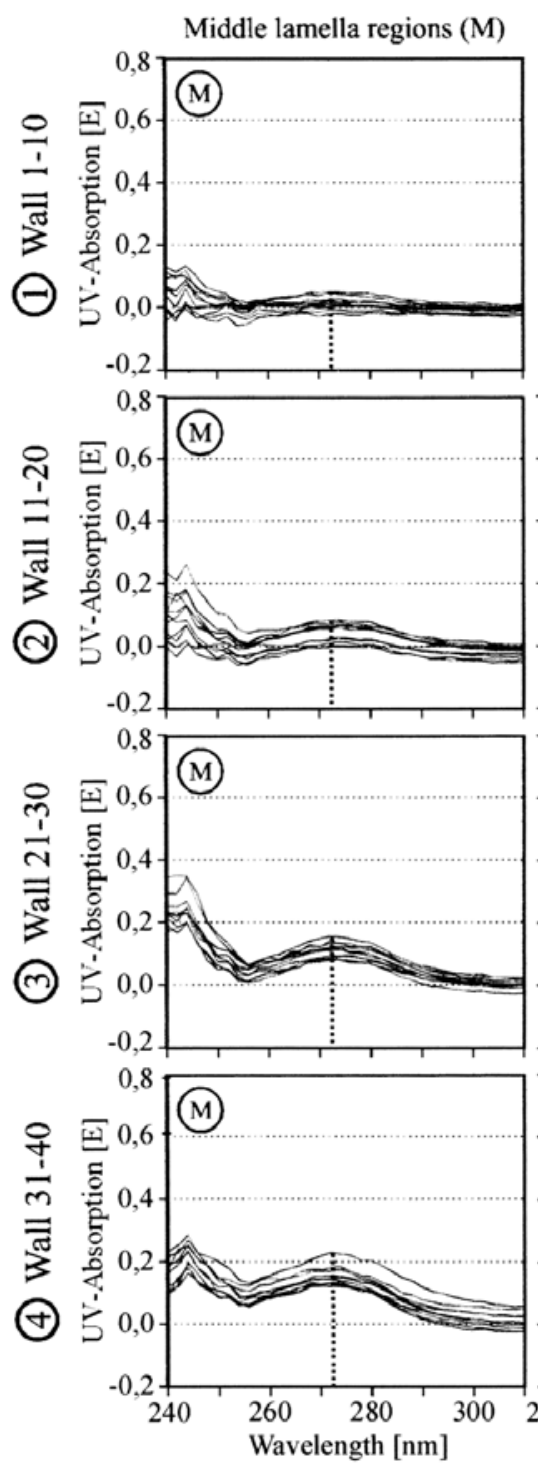

Secondary walls (S)
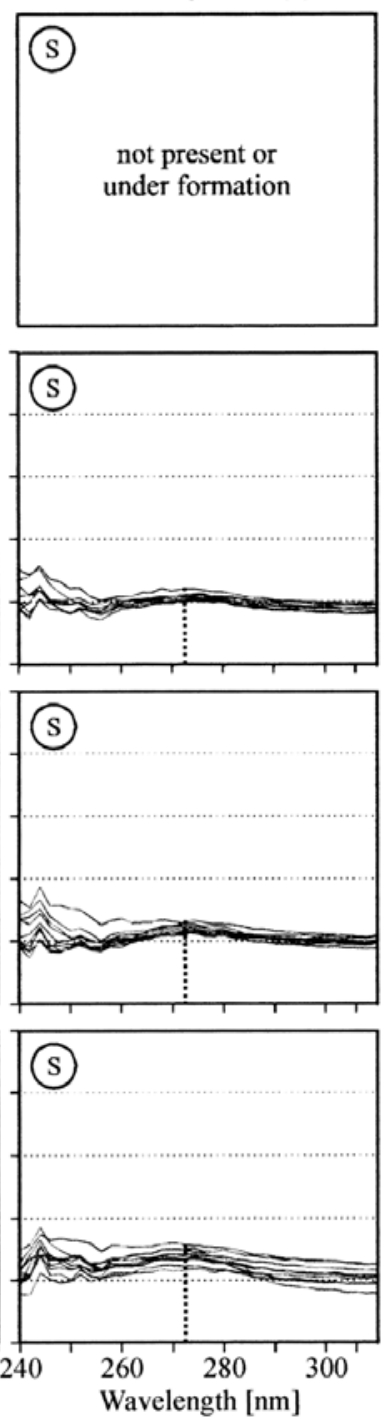

(b) Transgenic
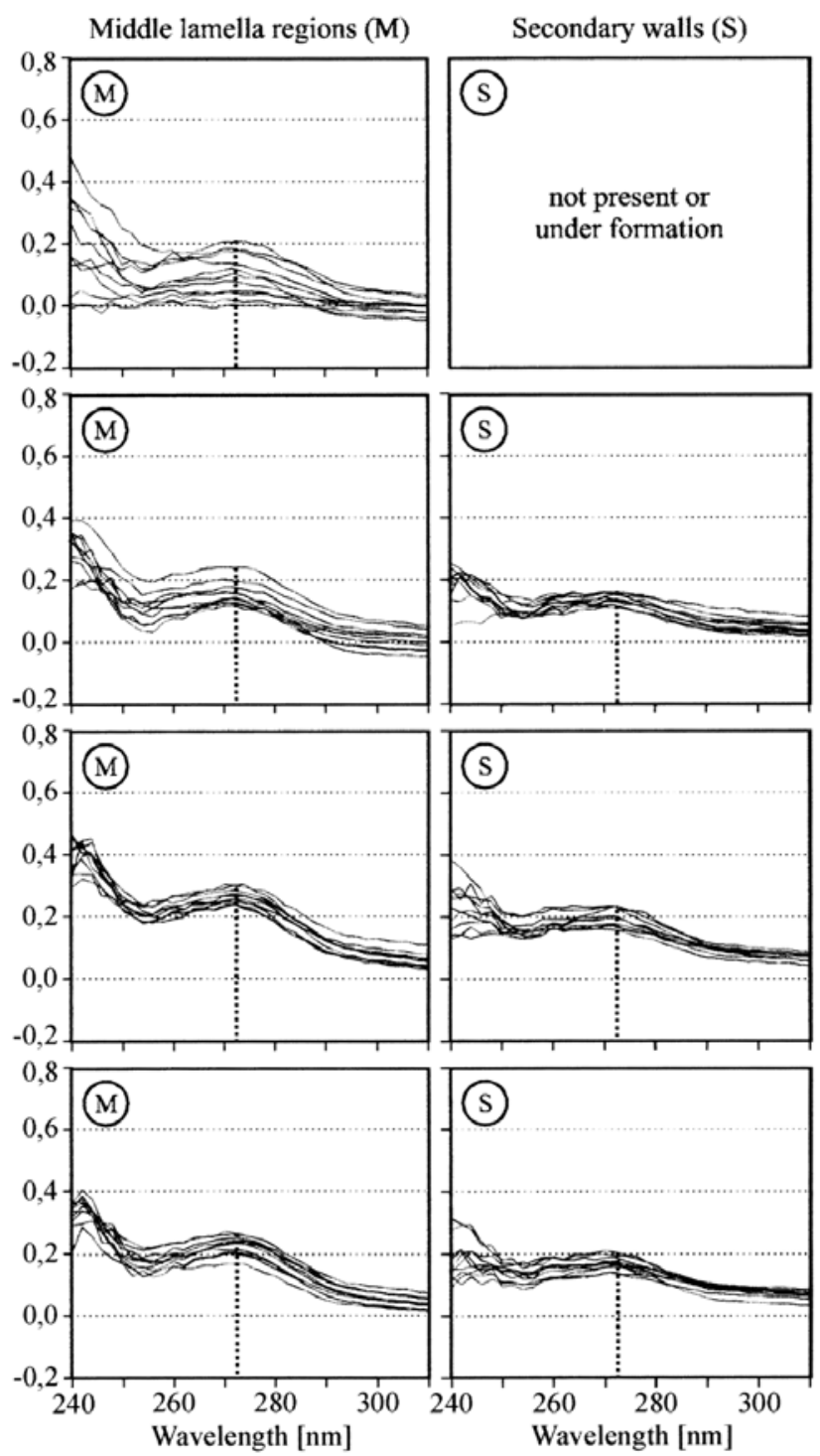

Figure 3. UV-absorption spectra of middle lamella regions (M) and secondary walls (S) of developing fibres. (1-4) Absorption at wavelengths around $272 \mathrm{~nm}$ increases with increasing distance from the cambium. (a) Wild type, (b) 35S-rolC transgenic tree. 
(a) Control
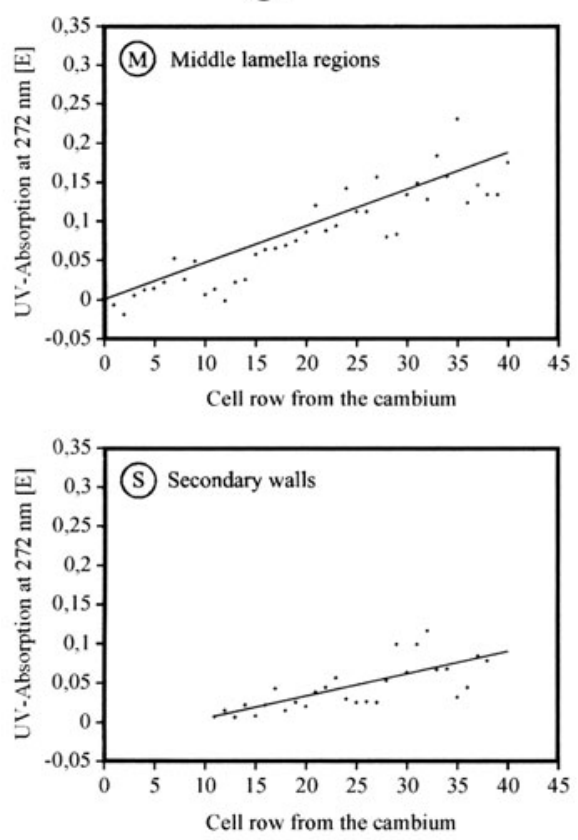

(b) Transgenic
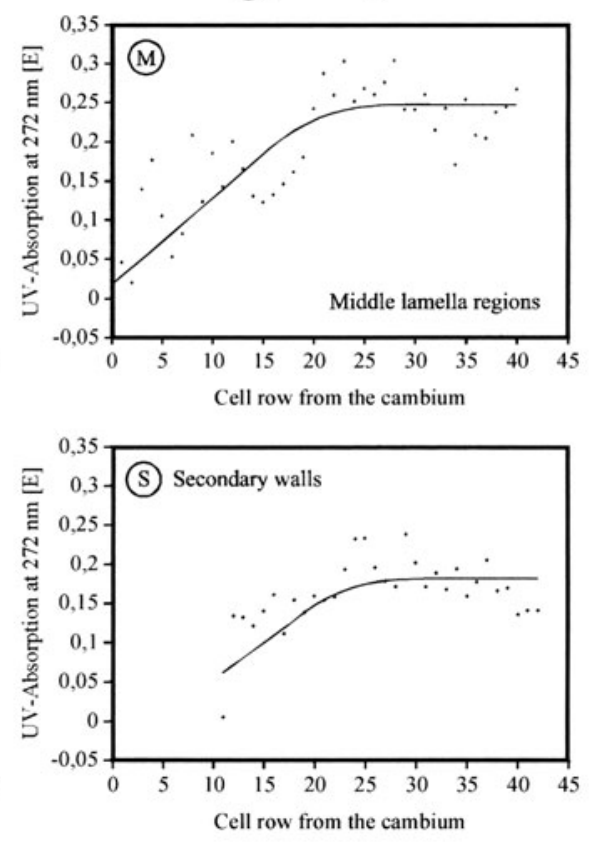

Figure 4. Changes in the UV-absorption at $272 \mathrm{~nm}$ measured in middle lamella regions (M) and secondary walls of developing fibres (S). (a) Wild type tree, linear increase of absorption up to cell row 40. (b) 35S-rolC transgenic tree, absorptions reach a plateau at about cell row 20 for middle lamellae and cell row 25 for secondary walls.

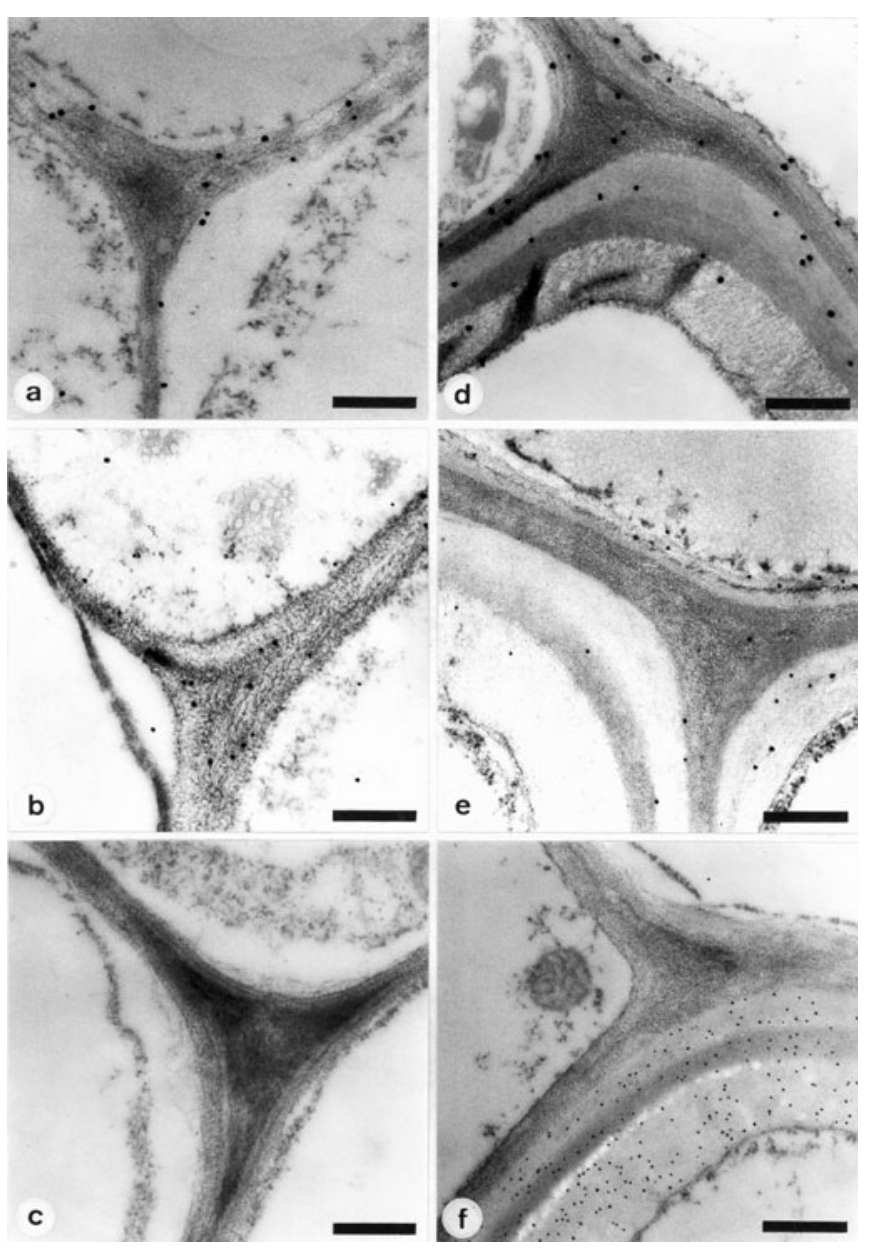

(figure $4 \mathrm{bM}$ ) and outer secondary walls (figure $4 \mathrm{bS}$ ) plateaus at about 20 cell rows from the cambium, whereas for the wild type the curves are still ascending throughout the 40 cell rows (figure $4 a M, a S$ ).

Immunogoldlabelling revealed the distribution of condensed guaiacyl (G), condensed guaiacyl/syringyl (GS) and non-condensed GS lignin sub-units in cell walls at very early developmental stages, close to the cambium (figure 5). Condensed lignin sub-units were localized in cell corners and intercorner middle lamellae without differences between wild type $(a, b)$ and transgenic trees $(d, e)$. However, non-condensed GS lignin sub-units were not labelled in the wild type trees $(c)$, whereas in the transgenics with distinct secondary wall formation these walls were densely labelled $(f)$.

Figure 5. (a-f) Electron micrographs, immunogoldlabelling of lignin sub-units $1-2$ cell rows from the cambium in wild type trees $(\mathrm{a}-\mathrm{c})$ and 35S-rolC transgenic trees $(\mathrm{d}-\mathrm{f})$, bars $=0.5 \mu \mathrm{m}$. (a, d) Condensed $\mathrm{G}$ lignin sub-units labelled in middle lamella regions of wild type trees (a) and middle lamella regions as well as secondary walls in transgenic trees (b). (b, e) Condensed G/S lignin sub-units labelled in middle lamella regions of wild type trees (b) and middle lamella regions as well as secondary walls in transgenic trees (e). (c, f) Non-condensed G/S lignin sub-units not labelled in wild type trees (c) but in secondary walls of transgenic trees (f). 


\section{DISCUSSION}

Besides new insights on the effects of constitutive rolC gene expression in $35 \mathrm{~S}$-rolC-transgenic aspen trees, the presented results provide evidence on basic differences in cell wall formation between aspen trees with normal and suppressed cambial activity. In the wild type trees, which are characterized by a broad differentiation zone, highly graduated developmental wood formation steps, especially regarding enlargement and secondary wall formation, could be clearly recognized as typical for fast-growing trees [7, 21]. Therefore, maturation of cell walls proceeded gradually as demonstrated for polysaccharide deposition and lignin incorporation. However, in the transgenics the differentiation zone was reduced to a few cell rows only probably due to reduced cambial activity. Therefore, the typical sequence of developmental steps could not be identified in our material. The commonly observed delay between polysaccharide deposition and lignin incorporation [36] was not seen in the transgenic trees as these wall components were deposited simultaneously. Further, maturation of cell walls was completed closer to the cambium as compared to the wild type trees. Microscopic analyses did not reveal significant differences in the structure of xylem cell walls between 35S-rolC transgenic and wild type trees. Although histometric measurements have shown slightly reduced vessel lumen areas and fibre lengths as well as thinner fibre cell walls in the 35S-rolC transgenic than in the wild type trees, no evidence was found for an alteration of cell wall chemistry in the differentiated wood $[15,16]$. Therefore, it can be concluded that in the wild type trees lignification was not completed within 40 cell rows from the cambium, even in middle lamella regions, which are known to lignify more rapidly and intensely than the secondary walls [36].

In agreement with Takabe [35] and Terashima [36], the first condensed lignin sub-units were detected in cell corner regions of transgenic and wild type trees adjacent to the cambium. However, this process occurred prior to, not during, S1 formation. Significant labelling of non-condensed GS lignin sub-units appeared in the transgenic and wild type trees immediately after the completion of S1 polysaccharide deposition. This developmental stage was found next to the cambium in transgenics, however, at more than seven cell rows distant to the cambium in the wild type trees. Yoshinaga et al. [44, 45] hypothesized that hardwood cell walls rich in guaiacyl lignin thicken rapidly and lignify slowly, whereas walls rich in syringyl lignin thicken and lignify slowly. Our results disagree with this hypothesis since the walls of transgenic and wild type trees did not differ in chemical composition but in the dynamics of cell wall thickening and lignification. It is therefore assumed that interrelationships between polysaccharide deposition and lignification depend on the spatial coordination of various steps during xylem formation. One of the most important steps is the rate of cell formation determining the distance of a developing cell to the cambium. Temporal aspects like the speed of metabolic pro- cesses also affect these interrelationships as shown by the parallel deposition of polysaccharides and lignin in the transgenic trees.

According to the continuum hypothesis proposed by Savidge [31], the place as well as the time moderates the differentiation of xylem cells by activation, duration and synchronization of structural gene expression. Auxin is assumed to be involved in the expression of homeotic genes regulating this spatio-temporal coordination [6]. It has long been considered to play a dominant role in regulating wood formation $[2,3,20,42]$. A more detailed concept published recently [34] suggests that auxin may control rate and duration of cell cycling as well as expansion of developing xylem cells by positional signalling. Therefore, auxin regulates the width of the developmental sub-zones cell division, expansion, and secondary wall formation. Regarding this concept, the reduced radial widths of differentiation zones in the $35 \mathrm{~S}$-rolC transgenic aspen trees may be due to altered auxin concentration gradients across the developing xylem and therefore altered positional information. Obviously, the cells released from the cambium remain extended periods close to the cambium. This might be responsible for the regular occurrence of well differentiated cells with lignified secondary walls additionally showing young walls centrally dividing the cell into two compartments. These young walls are normally not present in cells at progressed developmental stages.

In 35S-rolC transgenic aspen trees hormone measurements revealed differences in the ratios of cytokinins, abscisic acid and gibberellins of specific plant tissues as compared to the wild type trees, whereas the levels of indolacetic acid and the metabolites of ethylene biosynthesis were not significantly changed [13]. However, results on the initiation of cambial activity after winter dormancy has led to the assumption that in 35S-rolC transgenic aspen the basipetal transport of auxin, the sensitivity of the cambium to auxin or the ratio of auxin to other regulative factors may be altered [15]. These alterations may also be responsible for suppressed cambial activity and altered differentiation of xylem cells, though, evidence exists that auxin and other phytohormones as well as second messengers such as calcium moderate the control of cambial activity and vascular cell elongation by regulating uptake- and efflux carriers localized in the plasma membrane [30, 42, 43]. However, investigations of IAA modified transgenic aspen trees did not show any changes in the developmental pattern of cambial derivatives or the cambial growth rate [38]. Future research with $35 \mathrm{~S}-\mathrm{rolC}$ transgenic aspen trees should provide more detailed information on the distribution of phytohormones and proteins responsible for specific xylem differentiation patterns.

Acknowledgements: We gratefully acknowledge financial support for two short term scientific missions (EU COST E20) at CERMAV, France. We thank Dr. M. Fladung for providing the experimental trees, Prof. Dr. D. Eckstein and Prof. Dr. J.-P. Joseleau for discussions and C. Waitkus for supporting the photographic work. 


\section{REFERENCES}

[1] Allona I., Quinn M., Shoop E., Swope K., St Cyr S., Carlis J., Riedl J., Retzel E., Campbell M.M., Sederoff R., Whetten R.W., Analysis of xylem formation in pine by cDNA sequencing, Proc. Natl. Acad. Sci. USA 95 (1998) 9693-9698.

[2] Aloni R., Wood formation in deciduous hardwood trees, in: Raghavendra A.S. (Ed.), Physiology of trees, John Wiley \& Sons, New York, 1991, pp. 175-197.

[3] Aloni R., The induction of vascular tissues by auxin and cytokinin, in: Davis P.J. (Ed.), Plant hormones: physiology, biochemestry and molecular biology, Kluwer Academic Publ., Dordrecht, The Netherlands, 1995, pp. 531-546.

[4] Awano T., Takabe K., Fujita M., Daniel G., Deposition of glucuronoxylans on the secondary cell wall of Japanese beech as observed by immuno-scanning electron microscopy, Protoplasma 212 (2000) 72-79.

[5] Baba K., Asada T., Hayashi T., Relation between developmental changes on anatomical structure and on protein pattern in differentiating xylem of tension wood, J. Wood Sci. 46 (2000) 1-7.

[6] Baima S., Nobili F., Sessa G., Lucchetti S., Ruberti I., Morelli G., The expression of the ATHB-8 homeobox gene is restricted to provascular cells in Arabidopsis thaliana, Development 121 (1995) 4171-4182.

[7] Barnett J.R., Xylem cell development, Castle House Publications LTD, Tunbridge Wells, 1981.

[8] Chaffey N., Cambium: old challenges - new opportunities, Trees 13 (1999) 138-151.

[9] Delmer D.P., Amor Y., Cellulose biosynthesis, Plant Cell 7 (1995) 987-1000.

[10] Donaldson L.A., Lignin distribution during latewood formation in $\mathrm{Pi}$ nus radiata Don., IAWA Bull. 13 (1992) 381-387.

[11] Emons A.M.C., Mulder B.M., How the deposition of cellulose microfibrils builds cell wall architecture, Trends Plant Sci. 5 (2000) 35-40.

[12] Fladung M., Muhs H.J., Ahuja M.R., Morphological changes in transgenic Populus carrying the rolC gene from Agrobacterium rhizogenes, Silvae Genet. 45 (1996) 349-354.

[13] Fladung M., Grossmann K., Ahuja M.R., Alterations in hormonal and developmental characteristics in transgenic Populus conditioned by the rolC gene from Agrobacterium rhizogenes, J. Plant Physiol. 150 (1997) 420-427.

[14] Fladung M., Kumar S., Ahuja M.R., Genetic transformation of Рориlus genotypes with different chimoeric gene constructs: Transformation efficiency and molecular analysis, Transgenic Res. 6 (1997) 111-121.

[15] Grünwald C., Deutsch F., Eckstein D., Fladung M., Wood formation in rolC transgenic aspen trees, Trees 14 (2000) 297-304.

[16] Grünwald C., Ruel K., Joseleau J.-P., Fladung M., Morphology, wood structure and cell wall composition of rolC transgenic and non-transformed aspen trees, Trees 15 (2001) 503-517.

[17] Higuchi T., Biochemistry and molecular biology of wood, Springer-Verlag, Berlin, 1997.

[18] Joseleau J.-P., Ruel K., Study of lignification by noninvasive techniques in growing maize internodes. An investigation by FTIR, CP/MAS ${ }^{13} \mathrm{C}$ NMR and immunocytochemical transmission electron microscopy, Plant Physiol. 114 (1997) 1123-1133.

[19] Koch G., Kleist G., Application of scanning UV microspectrophotometry to localise lignins and phenolic extractives in plant cell walls, Holzforschung 55 (2001) 563-567.

[20] Larson P.R., Auxin gradients and the regulation of cambial activity, in: Kozlowski T.T. (Ed.), Tree growth, The Ronald Press Company, New York, 1962.

[21] Larson P.R., The vascular cambium. Development and structure, Springer-Verlag, Berlin, Heidelberg, New York, London, Paris, Tokyo, Hong Kong, Barcelona, Budapest, 1994.

[22] Lewis N.G., Davin L.B., Sarkanen S., Lignin and lignan biosynthesis: distinctions and reconciliations, in: Lewis N.G., Sarkanen S. (Eds.), Lignin and lignan biosynthesis, ACS Symposium Series 697, American Chemical Society, Washington DC, 1998, pp. 1-28.

[23] Maeda Y., Awano T., Takabe K., Fujita M., Immunolocalization of glucomannans in the cell wall of differentiating tracheids in Chamaecyparis obtusa, Protoplasma 213 (2000) 148-156.
[24] Nilsson O., Olsson O., Getting to the root: the role of the Agrobacterium rhizogenes rol genes in the formation of hairy roots, Physiol. Plant. 100 (1997) 463-473.

[25] Regan S., Bourquin V., Tuominen H., Sundberg B., Accurate and high resolution in situ hybridization analysis of gene expression in secondary stem tissues, Plant J. 19 (1999) 363-369.

[26] Ruel K., Comtat J., Barnoud F., Localisation histologique et ultrastructurale des xylanes dans les parois primaires des tissus d'Arundo donax, C. R. Acad. Sci. 284 (1977) 1421-1424.

[27] Ruel K., Barnoud F., Eriksson K.E., Ultrastructural aspects of wood degradation by Sporotrichum pulverulentum - Observations on spruce wood impregnated with glucose, Holzforschung 38 (1984) 61-68.

[28] Ruel K., Faix O., Joseleau J.P., New immunogold probes for studying the distribution of the different lignin types during plant cell wall biogenesis, J. Trace Microprobe T. 12 (1994) 247-265.

[29] Ruel K., Burlat V., Joseleau J.-P., Relationship between ultrastructural topochemistry of lignin and wood properties, IAWA J. 20 (1999) 203-211.

[30] Savidge R.A., Auxin and ethylene regulation of diameter growth in trees, Tree Physiol. 4 (1988) 401-414.

[31] Savidge R.A., Xylogenesis, genetic and environmental regulation (review), IAWA J. 17 (1996) 269-310.

[32] Savidge R.A., Biochemistry of seasonal cambial growth and wood formation - an overview of the challenges, in: Savidge R.A., Barnett J.R., Napier R. (Eds.), Cell and molecular biology of wood formation, BIOS Scientific Publ., Oxford, 2000, pp. 1-30.

[33] Sterky F., Regan S., Karlsson J., Hertzberg M., Rohde A., Holmberg A., Amini B., Bhalerao R., Larsson M., Villaroel R., Van Montagu M., Sandberg G., Olsson O., Teeri T.T., Boerjan W., Gustafsson P., Uhlén M., Sundberg B., Lundberg J., Gene discovery in the wood-forming tissue of poplar: Analysis of 5692 expressed sequence tags, Proc. Natl. Acad. Sci. USA 95 (1998) 13330-13335.

[34] Sundberg B., Uggla C., Tuominen H., Cambial growth and auxin gradients, in: Savidge R.A., Barnett J.R., Napier R. (Eds.), Cell and molecular biology of wood formation, BIOS Scientific Publ., Oxford, 2000, pp. $169-188$.

[35] Takabe K., Deposition of cell wall components in conifer tracheids, Ph.D. Thesis, University of Kyoto, Japan, 1984.

[36] Terashima N., Formation and ultrastructure of lignified plant cell walls, in: Kim Y.S. (Ed.), New horizons in wood anatomy, Chonnam National University Press, Kwangju, Korea South, 2000, pp. 169-180.

[37] Thiéry J.P., Mise en évidence des polysaccharides sur coupes fines en microscopie électronique, J. Microsc. 6 (1967) 987-1017.

[38] Tuominen H., Puech L., Regan S., Fink S., Olsson O., Sundberg B., Cambial-region-specific expression of the Agrobacterium iaa genes in transgenic aspen visualized by a linked uidA reporter gene, Plant Physiol. 123 (2000) 531-542.

[39] Tzfira T., Vainstein A., Altman A., Rol-Gene expression in transgenic aspen (Populus tremula) plants results in accelerated growth and improved stem production index, Trees 14 (1999) 49-54.

[40] Tzfira T., Vinucur B., Altman A., Vainstein A., Rol-transgenic Рориlus tremula: root development, root-borne bud regeneration and in vitro propagation efficiency, Trees 12 (1998) 464-471.

[41] Vander Mijnsbrugge K.V., Meyermans H., Van Montagu M., Bauw G., Boerjan W., Wood formation in poplar: identification, characterization, and seasonal variation of xylem proteins, Planta 210 (2000) 589-598.

[42] Wareing P.F., The physiology of cambial activity, J. Inst. Wood Sci. 1 (1958) 34-42.

[43] Wodzicki T.J., Auxin apical control of the auxin polar transport and its oscillation - a suggested cellular transduction mechanism, Acta Soc. Bot. Polon. 62 (1993) 37-41

[44] Yoshinaga A., Fujita M., Saiki H., Secondary wall thickening and lignification of oak xylem components during latewood formation, Mokuzai Gakkaishi 43 (1997) 377-383.

[45] Yoshinaga A., Akiyoshi K., Fujita M., Secondary wall thickening and lignification of xylem components in Betula grossa and Aesculus turbinata, in: Kim Y.S. (Ed.), New horizons in wood anatomy, Chonnam National University Press, Kwangju, Korea South, 2000, pp. 208-212. 
